\title{
TECHNOLOGICAL CHANGE AND ENVIRONMENTAL PROTECTION IN AGRICULTURAL DEVELOPMENT: CAN ECONOMIC AND ECOLOGICAL REASON BE A SYNERGISM?
}

\author{
Joko Mariyono ${ }^{1}$ \\ ${ }^{1}$ International and Development Economics, The Australian National University, \\ Canberra-Australia
}

\begin{abstract}
Sektor pertanian menjadi salah satu sumber pencemaran terbesar. Penyebabnya ada tiga kemungkinan: perubahan teknologi, model analisis ekonomi yang digunakan, dan kebijakan pemerintah. Hipotesisnya adalah penggunaan model ekonomi yang tidak tepat. Kajian ini mengevaluasi secara teoritis dan empiris model ekonomi, dan mengusulkan sebuah alternatif yang memungkinkan penurunan penggunaan input kimia pertanian. Dengan pendekatan teori produksi mikroekonomi dan ekonometri, kajian ini menunjukkan bahwa model analisis ekonomi yang digunakan selama ini tidak selalu benar dan mungkin menyesatkan. Untuk mendukung model alternatif yang diusulkan, kajian ini menggunakan satu unit data produksi pertanian dan pengenalan teknologi baru.

Hasil kajian ini menunjukkan bahwa bahwa pengenalan teknologi baru tidak serta merta menyebabkan produsen meningkatkan penggunaan input kimia. Perubahan teknologi yang telah menyebabkan pencemaran linkungan pada prinsipnya disebabkan oleh penggunaan model ekonomi yang direstriksi, yang didukung oleh kebijakan pemerintah. Oleh karena itu direkomendasikan untuk meninggalkan model yang direstriksi, dan menggantikannya dengan model yang dimodifikasi dalam mengevaluasi dampak ekonomi dari pengenalan teknologibaru, khususnya di sector pertanian. Terlihat bahwa alasan ekonomi dan ekologis dapat berjalan bersama-sama.
\end{abstract}

Kata kunci: perubahan teknologi, model ekonomi, regresi panel

\section{INTRODUCTION}

The United States Environmental Protection Agency (USEPA) reports that agriculture is one of the largest contributors to environmental pollution, particularly nonpoint source pollution (Archer and Shogren, 1994). This is because agricultural processes discharge agrochemical wastes exceeding the assimilating capacity of the environment. Non-point source pollution is a form of pollution whose source and quantity are very difficult to identify (Grafton et al., 2004). Barbier (1989) and Conway and Barbier (1990) call such conditions as unsustainable economic development. 
In reality, agriculture that leads to nonpoint source pollution has brought about considerably high external cost (Bond, 1996). Houndekon and de Groote (1998) report that the external cost of controlling migratory locust pests during 1992-1996 in Niger was around US $\$ 416,607$, the value of livestock poisoned by insecticides. In Thailand, Jungbluth (1999) reports that the external costs of pesticides in 1992 reached about US \$ 43 million, coming from the market value of pesticide-contaminated vegetables and fruits. In terms of health cost, each farmer in the Philippines must spend approximately an extra US \$24 for recovering health associated with $1 \mathrm{~kg}$ of pesticide application (Rola and Pingali, 1993).

Some studies also report that not only developing countries suffer from agricultural pollution problems. Agrochemical-pollution resulting in external cost also occurs in many developed countries. Germany estimates the amount of external costs related to the unintended undesirable side effects of agrochemical application. Every year, at least US \$ 164 million should be spent to deal with water contamination, residues in food, plants destroyed by herbicide, and loss in honey production. The ratio of such external costs to pesticide expenses is 23 per cent. Compared with the benefit value of pesticides, there is a net welfare loss of US \$ 587 million, which is equivalent to five per cent of net domestic agricultural product (Fleischer, 1999). Pincus et al. (1999) note that the net welfare loss related to agrochemical use also happens in the United States.

The pollution happens because of three factors. First, chemical inputs used are not perfectly captured by the production system, and are discharged into the environment (Cacho, 1999). The chemicals, then may be carried away and affect streams, lakes, urban drinking supplies and water tables. The amount of chemical discharged into the environment is dependent on the kinds of chemicals and the type of agricultural system. Pimentel et al. (1993) state that only one per cent of pesticide application will be on target, and the rest will be discharged into the environment.

Second, agrochemicals are detrimental to the environment. Ammonia released from nitrogenous fertilizers applied in agriculture, contributes to acid rain, while nitrates produced in soil contribute to the contamination of ground water, and the release of nitrogenous oxides contributes to ozone depletion. In addition, excessive chemical fertilizer use leads to compaction of soil since fertilizer has a relatively high content of ballast material accumulated in the soil and has a cementing effect. It also leads to killing bio-life in the soil, since the fertilizer concentration used is often toxic to the micro-life in the soil (Bond, 1996). Excess nutrients in the runoff from agricultural fields can also deplete surface water quality. This runoff supports population explosions of algae and invasive aquatic weeds, which in turn leads to oxygen depletion when these die and decay. With regard to human health, high levels of nitrates in drinking water can cause "blue baby syndrome" in infants and the formation of carcinogenic nitrosamines in human digestive tracts. In the air, the additional nitrous oxide added to the atmosphere contributes to respiratory illness (McLaughlin, 1999). Pesticides are poisonous agents 
designed to kill living things. Because of the fact that 'at sub cellular level organisms have many similarities with one another, all pesticides are associated with a certain measure of ... probability that some adverse effects will occur' (Wilkinson, 1988:11).

Third, the use of agrochemicals is increasing steadily. The Freedonia Group
(1995) and Bumb and Baanante (1996) show that the use of chemical fertilizers and pesticides among developed and developing countries are increasing, and use of fertilisers is even projected to increase until 2020 (see Figure 1 and Figure 2).

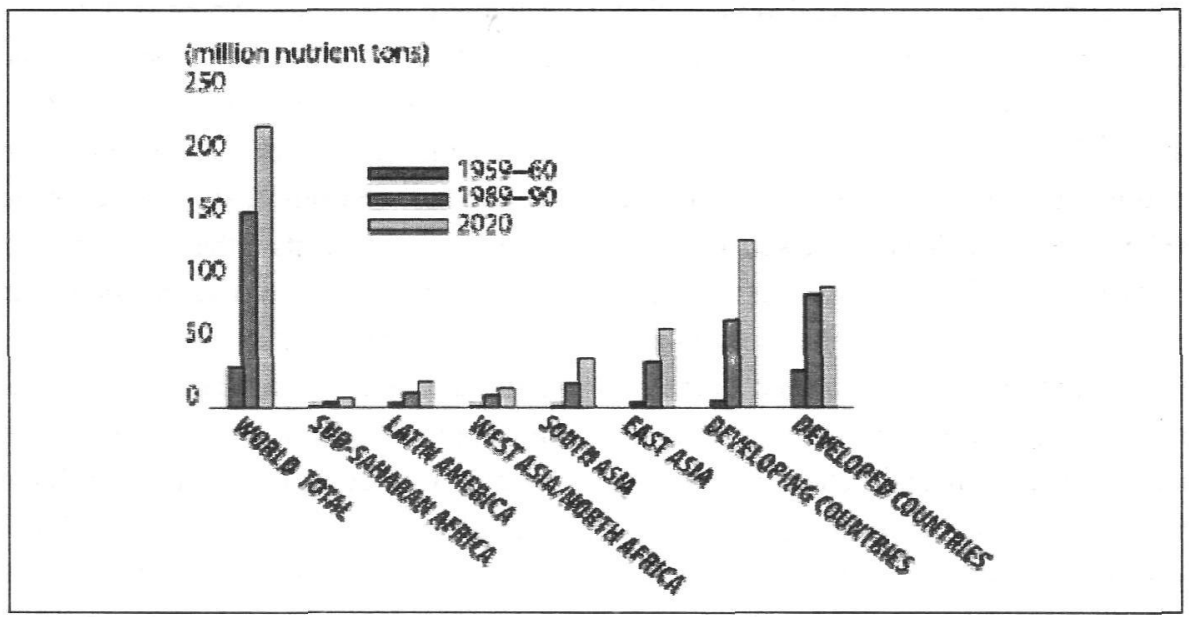

Source: Bumb, B. and Baanante, C., 1996. World Trends in Fertilizer Use and Projections to 2020, 2020 Brief, 38 (IFPRI, Washington, D.C) Table 1.

Figure 1. World Use of Chemical Fertilizer

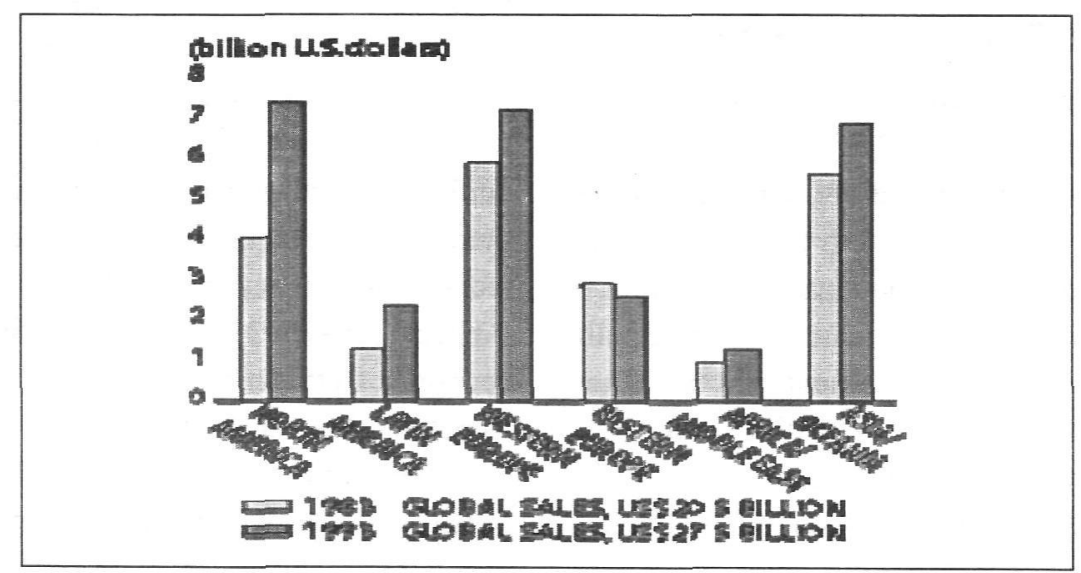

Source: The Freedonia Group, 1995. World Pesticides Report No. 636 (as cited in AGRO, No. 225: 16)

Figure 2. Pesticide Use in Developing Countries 
Non-point source pollution increases along with the steady increase in agrochemical use. Evidence demonstrates that there are continual increases in agrochemical use, and the question is why this is the case. There are three possible factors causing the increases in agrochemical use: technological change in agricultural, economic analysis, and government policy.

This paper makes a critical review that focuses on the economic analysis of technological change and government policy that has led to increased agrochemical use. Some previous studies on technical change and related issues will be reviewed to show that technological change has caused increases in input uses. By using economic theory on production and an econometric approach, this paper analyses microeconomic impact of technological change and its implications on agrochemical input uses. To support this critique, empirical evidence will show that economic analysis of technological change that has been used previously could be wrong, and resulting in misleading recommendations.

\section{LITERATURE REVIEW}

Technological progress in agriculture is frequently represented by the concept of agricultural modernisation. Janssen and de Londonõ (1994) distinguish three components in the process of modernization. The first is allocative efficiency, which is principally driven by changes in input prices. When inputs become less expensive and more readily available, allocative efficiency leads to intensification. The second is technical efficiency, which shifts the production function on which producers operate closer to the production frontier. The third is technical change, which moves up both average production and production frontier functions. Technical change is the application of previously unknown and unavailable techniques of production.

Allocative and technical efficiencies, first discussed almost fifty years ago by Farrell (1957), are usually studied simultaneously. This is because both measure economic efficiency, which is defined as the capacity of a firm to produce a predetermined quantity of output at minimum cost for a given level of technology (Farrell, 1957). Since efficiency analysis represents the performance of agricultural productivity, Saudolet and de Janvry (1995) offer those as standard methods for quantitative analysis of development policies. Consequently, a number of studies on technical efficiency of agricultural production in developing countries have been conducted to measure the performance of agriculture in relation to technological progress. The studies have resulted in a number of recommendations.

Thiam et al. (2001) review technical efficiency studies and use them for conducting a meta-analysis. The essential point of the work is that technical efficiency information is important in reflecting performance of agricultural production, and therefore the methods used in estimating technical efficiency matter. Bravo-Ureta and Pinheiro (1997: 63) who empirically studied economic efficiency in the Dominican Republic show that efficiency is still low, and they suggest that 'substantial gains in output ... can be attained given existing technology'. Umetsu et al.'s (2003) study of technical change and efficiency in the Philippine rice sector indicates that change in 
productivity of rice is related to the intensification caused by the green revolution. With respect to technological change, Coelli's (1996: 89) study of a neutrality of technological change in Australian agriculture concludes that 'material and services and labour were Hicks-saving relative to other input groups'.

Thus, most studies on efficiency and technological change suggest that efficiency needs to be raised by changing determining factors such as economic status through extension services, as well as policy interventions to enhance the socioeconomic status of producers that will result in increased agricultural production. The implication of the increased efficiency and technological change in agricultural production is increases in agrochemical input uses. This is because the technological changes move proportionately upward with the average production function, as well as increases in technical efficiency. Janssen and de Londonõ (1994) show that agricultural modernisation comprising efficiency and technological change lead to a considerable increase in agrochemical input use. It seems that there is a limitation of the current research, namely in economic models and econometric approached used to analyse the impact of technological change. The limitation makes it possible for agrochemical input use to increase continually.

\section{THEORETICAL FRAMEWORK}

Chambers (1988) and Antle and Capalbo (1988) explain that in studying economics, the dominant approach in economic analysis of production technologies has been to identify technology with movements in the production function. In this framework, the production function changes over time, but at a certain point of time, there is only one production function.

There are two types of changes in economic production resulting from a change in technology. Both can be diagrammatically expressed in Figure 3.

Figure 3 illustrates production of $\mathrm{Y}$ using single input $\mathrm{X}$. Let $\mathrm{Y}=\mathrm{F}^{0}(\mathrm{X})$ be initial production function. The production function results in supply for output and demand for input $\mathrm{S}_{\mathrm{Y}}^{0}$ and $\mathrm{D}_{\mathrm{X}}^{0}$ respectively. If the product and input markets are competitive, the producer aims to maximize profit, and the prices of $\mathrm{Y}$ and $\mathrm{X}$ respectively are $\mathrm{P}_{\mathrm{Y}}^{0}$ and $\mathrm{P}_{\mathrm{X}}^{0}$, the level of production will be $\mathrm{Y}^{0}$, and the level of input use will be $\mathrm{X}^{0}$, where marginal product of $\mathrm{X}\left[\mathrm{MP}_{\mathrm{X}}=\right.$ slope of $\left.\mathrm{F}^{0}(\mathrm{X})\right]$ is equal to the ratio $\mathrm{P}_{\mathrm{X}}^{0} / \mathrm{P}_{\mathrm{Y}}^{0}$.

Suppose now there is a technological change that shifts up the production function from $\mathrm{Y}=\mathrm{F}^{0}(\mathrm{X})$ to $\mathrm{F}^{1}(\mathrm{X})$. By holding an assumption that $\mathrm{P}_{\mathrm{Y}}^{0}$ and $\mathrm{P}_{\mathrm{X}}^{0}$, remain constant, producers will allocate inputs at $\mathrm{X}^{*}$, where the slope of $F^{1}(X)$ is equal to the ratio $\mathrm{P}_{\mathrm{X}}^{0} / \mathrm{P}_{\mathrm{Y}}^{0}$, and the new level of production is $\mathrm{Y}^{*}$. In both panel $\mathrm{A}$ and $\mathrm{B}$, supply for output, increases from $\mathrm{S}_{\mathrm{Y}}^{0}$ to $\mathrm{S}_{\mathrm{Y}}^{1}$, and the change in demand for input from $\mathrm{D}_{\mathrm{X}}^{0}$ to $\mathrm{D}_{\mathrm{X}}^{1}$ in both panels shifts in the opposite direction. 


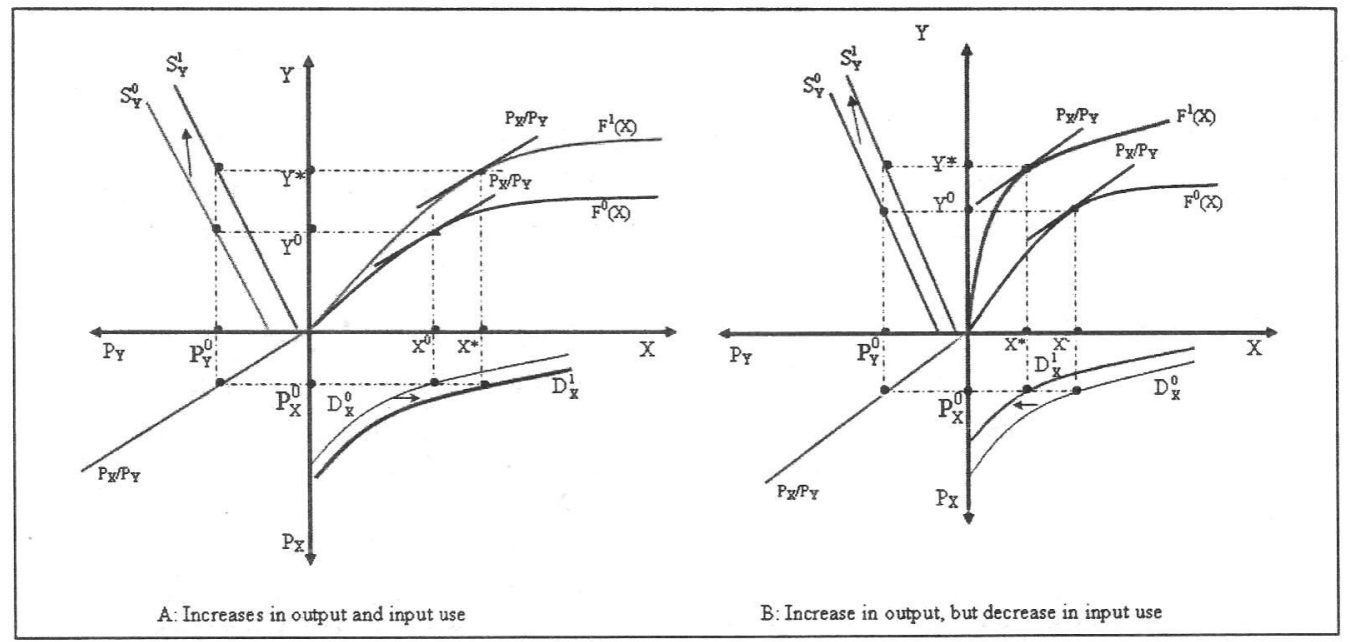

Figure 3. Impact of Technology on Eccnomic Production

In Panel $\mathrm{A}$, the figure shows that technological change leads to an increase in input use because with new technology, the same magnitude of $M P_{X}$ is reached at a higher level of input use. However in Panel $B$, the figure shows a different result. With new technology, the same magnitude of $M P_{X}$ is reached at a lower level of input use. In both cases, the changes in input use are due to profit maximizing.

Related to the fact that global use of agrochemicals has risen steadily, it seems that Model 1:A has been used in analysing the economic impact of introducing new technologies. This is because using this model will increase demand for agrochemicals. However, new technology is expected to increase efficiency, and therefore the same level of output is attainable with lower input. Consequently, new technology causing demand for input to decrease will be likely if Model 1:B is used.

Figure 4:A, can be expressed mathematically in terms of Cobb-Douglas production technology, with a single output and single input as follows:

$Y=A X^{\alpha} e^{\delta T}$

where $\mathrm{Y}$ is production, $\mathrm{A}$ is total factor productivity, $\mathrm{X}$ is variable input, and $\mathrm{T}$ represents technology change. Millan and Aldaz (1998) state that the inclusion of $\mathrm{T}$ in time series econometric models of production is to measure technological change over time. Kompas et al. (2004) employ the model to estimate a production function to measure technical efficiency. The model implies that technological change only affects the total factor productivity, A. The marginal product of $\mathrm{X}$ resulting from the production function is:

$$
\mathrm{MPX}=\alpha \mathrm{AX}^{\alpha-1} \mathrm{e}^{\delta \mathrm{T}}
$$

Since $\delta$ is expected to be positive, the technological change brings about increases in both demand for $\mathrm{X}$ and supply for $\mathrm{Y}$. 
Figure $4: B$ on the other hand, can be mathematically expressed as:

$$
Y=A X^{\alpha+\gamma T} e^{\delta T}
$$

In this case, technological change does not only affect the total factor productivity, A, but also affects elasticity of production with respect to $\mathrm{X}, \alpha$. The marginal product of $\mathrm{X}$ is going to be:

$$
\mathrm{MP}_{\mathrm{X}}=(\alpha+\gamma \mathrm{T}) \mathrm{X}^{\alpha+\gamma \mathrm{T}-1} \mathrm{e}^{\delta \mathrm{T}}
$$

In this sense, $\delta$ is still expected to be positive. Now however, an increase in $\mathrm{T}$ will have three possible outcomes, which is dependent on the signs and magnitude of $\gamma$. First, if $\gamma$ is positive, or negative but small in magnitude, an increase in $\mathrm{T}$ will lead to a higher marginal product at the same level of input use, and as a consequence, there is an increase in input use to maximise profit. Second, if $\gamma$ is negative such that marginal product at the same level of input use is the same as that when there is an increase in $\mathrm{T}$, the implication is that input use does not change. Third, if $\gamma$ is negative and the magnitude of $\gamma$ is big enough such that the marginal product at the same level of input use is lower than that when there is an increase in $\mathrm{T}$. This results in a decrease in input use as a consequence of the increase in technological change.

The difference between Model 1:A and Model 1:B comes from imposing the restriction of $\gamma=0$. If the restriction is imposed on Model 1:B, both models will be exactly the same. However, imposing the restriction is not always acceptable. It is required to test whether or not the restriction is correctly imposed. If the test rejects the restriction, the policy implication will be misleading.

Testing the third case, where demand for $\mathrm{X}$ decreases because of technological change, can be done by estimating the production function. The demand for $\mathrm{X}$ is then derived from the estimated production function. However, estimating the production function is complicated, since it has various functional forms. Estimating the production function also has a risk of selecting incorrect production function. Once the functional form of the production function is incorrectly selected, the demand for $\mathrm{X}$ is inappropriate as well. Related to econometric estimation, Kumbhakar (1988a; 1988b) argue that estimating the production function will result in biased estimator. This is because under assumption of profit maximisation, the use of vector input is endogenous, which is dependent on prices of inputs and price of output. Under the assumption of profit maximisation, Kumbhakar (1988a; 1988b) propose to estimate demand function for input and supply function for output, which is derived from profit function. It is, therefore, straightforward to estimate directly the demand function for $\mathrm{X}$ and supply function for $\mathrm{Y}$, which are capable of indicating the third case. Corresponding to Hotelling's lemma in Jehle and Reny (2001), let the well-behaved production function be:

$$
Y=f\left(\mathbf{X}_{i}, Z_{i}, T\right)
$$

where $\mathbf{X}_{\mathrm{i}}$ is vector of variable inputs, $\mathbf{Z}_{\mathrm{i}}$ is vector of fixed inputs and $\mathrm{T}$ is technology. The production function is assumed to be strictly concave, continuously twicedifferentiable in both $X_{i}$ and $T$, and the 
marginal product of each input is positive and decreasing. If $\mathrm{P}_{\mathrm{X}} \mathrm{i}$ and $\mathrm{P}_{\mathrm{Y}}$ are prices of input and output respectively, the demand function for $\mathrm{X}$ and supply function for $\mathrm{Y}$ corresponding to profit maximisation are respectively expressed as:

$$
\begin{aligned}
& X=D\left(P_{X i}, P_{Y}, Z, T\right) \\
& Y=S\left(P_{X i}, P_{Y}, Z, T\right)
\end{aligned}
$$

When $\partial \mathrm{X} / \partial \mathrm{T}<0$ and $\partial \mathrm{Y} / \partial \mathrm{T}>0$ holds, the third case occurs in which $\gamma$ is large enough relative to $\delta$. This implies that new technology brings about input use to decrease.

\section{EMPIRICAL EVIDENCE}

\section{- Material and Methodology}

This study uses the case of Java, Indonesia where information on technology and data on production are well documented and available. The data are compiled from a number of sources including the Annual Report of the Provincial Agricultural Office, and statistical data published by the Provincial and District Statistical Offices.
This study that contends with data collection, data database management, data transformation and econometrical analysis is carried out in 2002-2003. There is no need to apply certain sampling method since this study use secondary time series data. Locations are selected based on the availability of data. The selected locations are expected to be representative since the data is aggregation of all farmers in each location during one year. Rice is chosen as the object of this study since it the major commodity. The agrochemical input to be analysed is pesticide use, because pesticides have more damaging environmental effects than other agrochemicals.

The data used in this study comprise four districts in nine-year period (1990-98), in which there was dissemination of IPM technology. Types of data to analyse are: annual production of rice, annual use of pesticides, number of training on technology (unit), annual average price of rice (Indonesian Rupiah=IDR per $\mathrm{kg}$ ), annual average price of fertilizers and pesticides (IDR per $1 / \mathrm{kg}$ ), and the amount of land. Summary statistics for variables used in this study can be seen in Table 1 .

Table 1. Summary Statistics for Variables

\begin{tabular}{lcrrrr}
\hline Variable & Obs. & \multicolumn{1}{c}{ Mean } & \multicolumn{1}{c}{ Std. Dev. } & \multicolumn{1}{c}{ Min } & \multicolumn{1}{c}{ Max } \\
\hline Pesticide use & 40 & 863.29 & 725.31 & 50.3 & 2484 \\
Rice Production & 40 & 146310.50 & 94106.09 & 21896 & 303153 \\
Price of rice & 40 & 439.47 & 213.44 & 263.25 & 1147 \\
Price of pesticides & 40 & 6665.61 & 1798.68 & 4273.64 & 11229.48 \\
Price of fertilizers & 40 & 735.14 & 281.84 & 364.96 & 1305.24 \\
Unit of training & 40 & 159.10 & 129.67 & 4 & 391 \\
Area & 40 & 24599.67 & 15697.02 & 5409 & 50589 \\
\hline
\end{tabular}

Note: Author's calculation 


\section{- Model Estimation}

For the sake of simplicity, both demand function for pesticides and supply for rice derived from profit maximisation are arbitrarily set to be linear forms in prices, and semi log in technological change. The reason is that this study pays close attention to the sign of coefficient on each variable analysed, instead of the magnitude of the coefficient. Difference in functional forms of demand and supply is expected to give the same sign, even though the magnitude will be different due to different scale. The demand function for pesticides is:

$$
\begin{aligned}
X= & \beta_{0}+\beta_{1} P_{X}+\beta_{2} P_{Y}+\beta_{3} P_{F}+\beta_{4} L+ \\
& \beta_{5} \ln T
\end{aligned}
$$

and the supply function for rice is:

$$
\begin{gathered}
\mathrm{Y}=\phi_{0}+\phi_{1} \mathrm{P}_{\mathrm{X}}+\phi_{2} \mathrm{P}_{\mathrm{Y}}+\phi_{3} \mathrm{P}_{\mathrm{F}}+\phi_{4} \mathrm{~L}+ \\
\phi_{5} \ln \mathrm{T}
\end{gathered}
$$

where $\mathrm{X}$ is pesticides, $\mathrm{Y}$ is rice, $\mathrm{P}_{\mathrm{X}}$ is price of pesticides, $P_{Y}$ is price of rice, $P_{F}$ is price of fertilisers, $\mathrm{L}$ is land, and $\mathrm{T}$ is number of training on new technology, which is a technology proxy dissemination. The technology is taken in log form because it represents the percentage change in the number of training on such technology.

Test hypotheses that can be formulated from both functions are:

$$
\begin{aligned}
& \mathrm{H}_{0}: \partial \mathrm{X} / \partial \ln \mathrm{T}=0 ; \text { and } \partial \mathrm{Y} / \partial \ln \mathrm{T}=0 \\
& \mathrm{H}_{1}: \partial \mathrm{X} / \partial \ln \mathrm{T}<0 \text {; and } \partial \mathrm{Y} / \partial \ln \mathrm{T}>0
\end{aligned}
$$

Estimation of the supply and demand functions is conducted using panel regressions. Both models are not considered to be simultaneous, because production and pesticide use are the responses of producers to any changes in market prices. If the quantity of rice and pesticides come from the quantities sold in the market, both supply for rice and demand for pesticide functions will be simultaneous with demand for rice and supply for pesticide functions respectively. The estimation consequently should be done using a simultaneous model (Greene, 2003).

\section{RESULTS AND DISCUSSION}

The supply function for rice, and the demand function for pesticides in rice farming, which are estimated using random effect, are respectively shown in Table 2 and Table 3 . A Hausman test has been done to determine whether a fixed effect or random effect is suitable in this case. The test indicates that there is no statistical difference between fixed and random effects. Thus the estimates reported in this paper are the random effect models, because these models are more efficient (Wooldridge, 2003; Greene, 2003). It is indicated that the joint test for coefficients on prices are significant in both demand for pesticides and supply for rice, but testing individually for those coefficients shows us that prices are not significant. This is due to usual phenomena, called multicollinearity problems, resulting from high correlation among prices over time. Such problem makes this analysis is not able to separate the impacts of prices individually. This paper, however, pays closer attention to technological change, and does not highlight the price factor much. Thus, it is sufficient to test jointly the significance of coefficients on prices. 
Table 2. Supply Function for Rice

\begin{tabular}{lrr}
\hline \multicolumn{1}{c}{ Independent variable } & Coefficient & z-ratio \\
\hline Constant & 10961 & 0.47 \\
Price of rice & 31.73 & 0.42 \\
Price of fertilizer & -18.17 & 0.62 \\
Price of pesticide & -7.69 & 0.14 \\
Technology & 9517.1 & $2.13^{*}$ \\
Rice-planted area & 5.81 & $43.13^{\star \star}$ \\
\hline$\chi^{2}$ joint test for restriction of price coefficients $=0$ & $12.46^{\star \star}$ & \\
$\mathrm{R}^{2}$ & 98.71 & \\
\hline
\end{tabular}

Notes: Dependent variable: rice production (tons);

**) significant at $\alpha=0.01$; ") significant at $\alpha=0.05$

Source: author's estimations

Table 3. Demand Function for Pesticides in Rice Farming

\begin{tabular}{lcc}
\hline Independent variable & Coefficient & z-ratio \\
\hline Constant & 2560 & 3.41 \\
Price of rice & 2.97 & 1.56 \\
Price of fertilizer & 0.99 & 0.56 \\
Price of pesticide & -0.32 & -1.25 \\
Technology & -470.42 & $-2.16^{*}$ \\
Rice-planted area & 0.02 & $3.24^{\text {** }}$ \\
\hline$\chi^{2}$ joint test for restriction of price coefficients $=0$ & $8.53^{*}$ & \\
$\mathrm{R}^{2}$ & 48.63 & \\
\hline
\end{tabular}

Note: Dependent variable: pesticide use $(\mathrm{kg}){ }^{*}$ ) significant at $\alpha=0.01$; ${ }^{*}$ ) significant at $\alpha=0.05$ Source: author's estimation

Based on estimated supply for rice and demand for pesticides, it is not difficult to see that technology reduces pesticide use and boosts rice production at the same time. Both shifts in the functions of demand for pesticides and supply for rice are due to profit maximising. The point of interest of this finding is that technology does not only increase productivity, but also reduces the elasticity of production with respect to pesticides.

Recall the third case for which $\gamma$ is large enough compared to $\delta$. Since technological change is capable of diminishing demand for inputs, using the economic model to analyse technological change that imposes the restriction of $\gamma=0$ on the production function is not always the case. This indicates that the production function is changed when new technology is adopted. In other words, the elasticity of production with respect to pesticide use decreases as a result of the increase in technology. This implies that the technological change is chemical saving. This phenomenon seems to be parallel to the findings of Coelli (1996) and Michl (1999) 
revealing that technology change is not always typically neutral.

However, the global use of agrochemicals is steadily increasing. Based on these findings, it is likely that technological change is not the cause of the global increase in agrochemical use. The most likely cause of increasing agrochemical use is the use of an economic model that imposes incorrectly the restriction of $\gamma=0$, and government policy that promotes rapid growth in the agricultural sector.

In the case of Indonesian agriculture, the increase in agrochemical use during the implementation of the green revolution was due largely to the fact that the government subsidised agrochemicals to support the green revolution (Barbier, 1989). The policy of subsidising agrochemical use had objectives of raising rice productivity and reaching food self-sufficiency. This policy was strongly implemented in Java, which is the Indonesian rice-bowl area. However, in relation to the fact that pesticide use has decreased in particular area studied here, the government has changed the agricultural policy from chemical intensive agriculture to an environmental friendly policy since 1986 (Untung, 1996). The implementation of the policy started in 1989 when new technology was introduced, and the subsidy on pesticides was waived (Useem et al., 1992).

Generally, in developing countries where the agricultural sector plays an important role in the economy, it is likely that policy makers use the economic model which results in increases in production and input use, to boost growth in the agricultural sector. Umetsu et al. (2003) argue that technological change is intended to intensify use of packages of technology that highly substitute for land, although the option has a consequence of increasing environmental problems, and lowering profits. This is in line with the view that there is a trade-off between growth and environmental quality. When growth is more important than the environment, for instance in poor African countries, this choice is sensible. Kidane and Abler (1994) attempt to find production technology to improve agricultural performance in Ethiopia, where there is a severe food problem. Using the model proposed in this paper is not appropriate, because reducing inputs will result in lower production level. Furthermore if the demand for inputs decreases, agrochemical industries will become idle. However, in developed countries where the agricultural sector is less important, it is necessary to choose a policy that is environmentally sound. Using the model proposed in this paper could be relevant, and the producers would be capable of maximising profit and increasing the quality of the environment.

\section{CONCLUSION}

The agricultural sector in developed and developing countries has contributed to nonpoint source pollution due largely to the increasing use of agrochemical inputs, which are detrimental to the environment. The increase is triggered by an action called the "green revolution" introducing new agricultural technology. The technology is a package of agronomical and chemical measures. The empirical evidence, however support the idea that the introduced technology itself is not the main culprit. Government policy and economic models used in evaluating the impact of introduced technology on the economics of production 
have caused the increase in agrochemical input use.

In the case of Indonesia, during the implementation of the green revolution, the government strongly supported agrochemical use by providing huge subsidies. Thus, the agrochemical input use increased dramatically. Subsequently, this resulted in non-point source pollution. However, the decrease in pesticide use after 1989 is due mostly to changes in agricultural policy, consisting of introducing new technology and waiving pesticide subsidies (see Appendix 1).

There appears to be a link between the economic model of analysis and government policy. If the policy targets high production, the economic model that yields an outcome of reducing input use is not favourable, because it will cause the level of production to be lower and make other industries idle. In this sense, government policy prefers to use economic models that enable outcomes of increased production and input use. This is because the level of production with new technology is higher than that with existing technology, although profits are not maximised. However, if the policy aims to obtain high profits and high quality of the environment, the outcome of reducing agrochemical inputs and increasing output is ideal. If it is the case, selecting the economic model for evaluating the economic impact of technological change becomes very important. Once policy makers select an incorrect model, the implication will not be in line with the policy's objectives.

From the empirical analysis, there is evidence that new technology that has been introduced since 1989 is capable of reducing demand for pesticides and increasing supply for rice at the same time. The implication is that the analytical tool that has been currently used to analyse the impact of technological change could be inappropriate, and this results in the wrong recommendations.

Based on the empirical analysis, it is recommended that policy makers employ appropriate analytical tools if the policy concerns environmental quality. Increasing environmental quality will improve the welfare of the whole community since, with the better quality of environment; people will have a higher standard of living. Furthermore, in relation to the global awareness of environmental issues, it is preferable to use economic models that enable reduced agrochemical use, and to abandon the analysis that leads to increased use. Since the economic model used in this paper is straightforward and easy to apply, compared with estimating the production function, this model has become one of the alternatives for quantitative analysis of economic development.

\section{REFERENCES}

Antle, J.M. and S.M. Capalbo. 1988. An Introduction to Recent Developments in Production Theory and Productivity Measurement'. In S.M. Capalbo, and J.M. Antle (eds), Agricultural Productivity: Measurement and Explanation. Resource for the Future, Washington, DC.

Archer, D.W. and J.F. Shogren. 1994. Non Point Pollution, Weed and Risk. J. Agric. Econ. 4 (1): 38-51.

Barbier, E.B. 1989. Cash Crops, Food Crops, and Sustainability: the Case of 
Indonesia. World Development, 17 (6): 879-895.

Bond, J. W. 1996. How EC and World Bank Policies are Destroying Agriculture and the Environment. Singapore: AgBé Publishing.

Bravo-Ureta, B.E. and A.E. Pinheiro. 1997. Technical, Economic, and Allocative Efficiency in Peasant Farming: Evidence from the Dominican Republic', The Dev. Econ. 35(1): 48-67.

Bumb, B. and C. Baanante. 1996. World Trends in Fertilizer Use and Projections to 2020. International Food Policy Research Institute, 2020 Brief, 38, Washington, D.C.

Cacho, O.J. 1999. Dynamic Models, Externalities and Sustainability in Agriculture, Working Paper Series in Agricultural and Resource Economics 99-4 - April 1999 The University of New England.

Chambers, R. G. 1988. Applied Production Analysis: a Dual Approach. New York: Cambridge Univ. Press.

Coelli, T. J., 1996. Measurement of total Factor Productivity Growth and Biases in Technological Change in Western Australia Agriculture. J. App. Econometrics, 11:77-94.

Conway, G. R. and E.B. Barbier, 1990. After Green Revolution, Sustainable Agriculture for Development. London: Earthscan Pub.

Farrell, M.. 1957. The Measurement of Productivity Efficiency. J. Royal Stat. Society, series A 120 (3): 253-290.

Fleischer, G. 1999. The Role of Economic Analysis of Pesticide Use and Policy
Experiences from Country Case Studies, A Publication of the Pesticide Policy Project. Special Issue, 1:208-22.

Freedonia Group.1995. World Pesticides, Report No. 636 (The Freedonia Group, Cleveland, Ohio.

Grafton, R.Q., W. Adamowicz, D. Dupont, H. Nelson, R.J. Hill and S. Renzetti. 2004. The Economics of the Environment and Natural Resources, Carlton: Blackwell Publishing.

Greene, W.H. 2003. Econometric Analysis. New Jersey: Prentice Hall.

Houndekon, V. and H. de Groote. 1998. Health Costs and Externalities of Pesticides Application in Locust and Grasshopper Control in the Sahel. Paper Prepared for the Annual Conference of the American Agricultural Economics Association, 2-5 Aug. 1998, Utah.

Jansen, W. and N.R. de Londonõ. 1994. Modernization of Peasant Crop in Columbia: Evidence and Implications. Agric. Econ. 10: 13-25.

Jehle, G. A. and P.J. Reny. 2001. Advanced Microeconomic Theory. AddisonWesley, Boston.

Jungbluth, F. 1996. Crop Protection Policy in Thailand: Economic and Political Factors Influencing Pesticide Use. A Publication of the Pesticide Policy Project 5.

Kidane, A. and D.G. Abler. 1994. Production Technology in Ethiopian agriculture. Agric. Econ. 10: 179-191.

Kompas, T., T.N. Che and R.Q. Grafton. 2004. Technical Efficiency Effects of Input Controls: Evidence from 
Australia's Banana Prawn Fishery. App. Econ. 36: 1631-1641.

Kumbhakar, S.C., 1988a. 'On the Estimation of Technical and Allocative Efficiency Using Stochastic Frontier Function: the Case of U.S. Class 1 Railroads', International Economic Review, 29(4): 727-43.

Kumbhakar, S.C., 1988b. 'Estimation of Input-Specific Technical and Allocative Efficiency in Stochastic Frontier Models', Oxford Economic Papers, 40:535-49.

McLaughlin, S. P. 1999. Sustainability Issues in Modern Agriculture. http://ag. arizona.edu/OALS/oals/alrsgp/faculty/ mclaughlin/issues.html (1 Feb. 1999).

Michl, T.R. 1999. Biased Technical Change and the Aggregate Production Function. Int'l. Rev. of App. Econ.. 13(2): 193206.

Millan, J.A. and N. Aldaz. 1998. Agricultural Productivity of the Spanish Regions: a non-Parametric Malmquist Analysis. App. Econ. 30: 875-884.

Pimentel, D., H. Acquay, M. Biltonen, P. Rice, M. Silva, J. Nelson, V. Lipner, S. Giordano, A. Horowitz and M. D'Amore. 1993. 'Assessment of Environmental and Economic Impacts of Chemical Pesticides Use', in D. Pimentel and H. Lehmann (eds), The Chemical Pesticides Question Environment, Economics and Ethics, New York: Chapman \& Hall.

Pincus, J., H. Waibel and F. Jungbluth. 1999. Pesticide Policy: An International
Perspective. Pesticide Policy Project Publication Series, 7: 4-22.

Rola, A.C. and P.L. Pingali. 1993. Pesticides, Rice Productivity, and Farmer's Health: an Economic Assessment, IRRI and World Resource Institute, Washington.

Sadoulet, E. and A. de Janvry, 1995. Quantitative Development Policy Analysis, Baltimore: The John Hopkins Univ. Press.

Thiam, A., B.E. Bravo-Ureta and T.E. Rivas. 2001. Technical Efficiency in Developing Country Agriculture: a Meta-Analysis. Agric. Econ. 25:235-243.

Umetsu, C., T. Lekprichakul, and U. Chakravorty. 2003. Efficiency and Technological Change in The Philippine Rice Sector: A Malmquist Total Factor Productivity Analysis. Amer. J. Agric. Econ. 85(4): 943-963.

Untung, K., 1996. Institutional Constraints on IPM Implementation in Indonesia. Publication of the Pesticide Policy Project, Publication Series, 3A: 37-47.

Useem, M., L. Setti and J. Pincus. 1992. The science of Javanese Management: Organizational Alignment in an Indonesian Development Programme. Public Adm. and Dev. 12: 447-471.

Wilkinson, C.F. 1988. Introduction and Overview, in S.R. Baker, and C.F. Wilkinson, (eds), The Effects of Pesticides on Human Health. Princeton: Princeton Scientific Publishing Co. Inc. 5-33.

Wooldridge, J.M., 2003. Introductory Econometrics: a Modern Approach, SouthWestern College Publishing. 
Appendix 1: Trends in Pesticide and Insecticide Uses in Indonesia

A: Pesticide Use in the Study Area

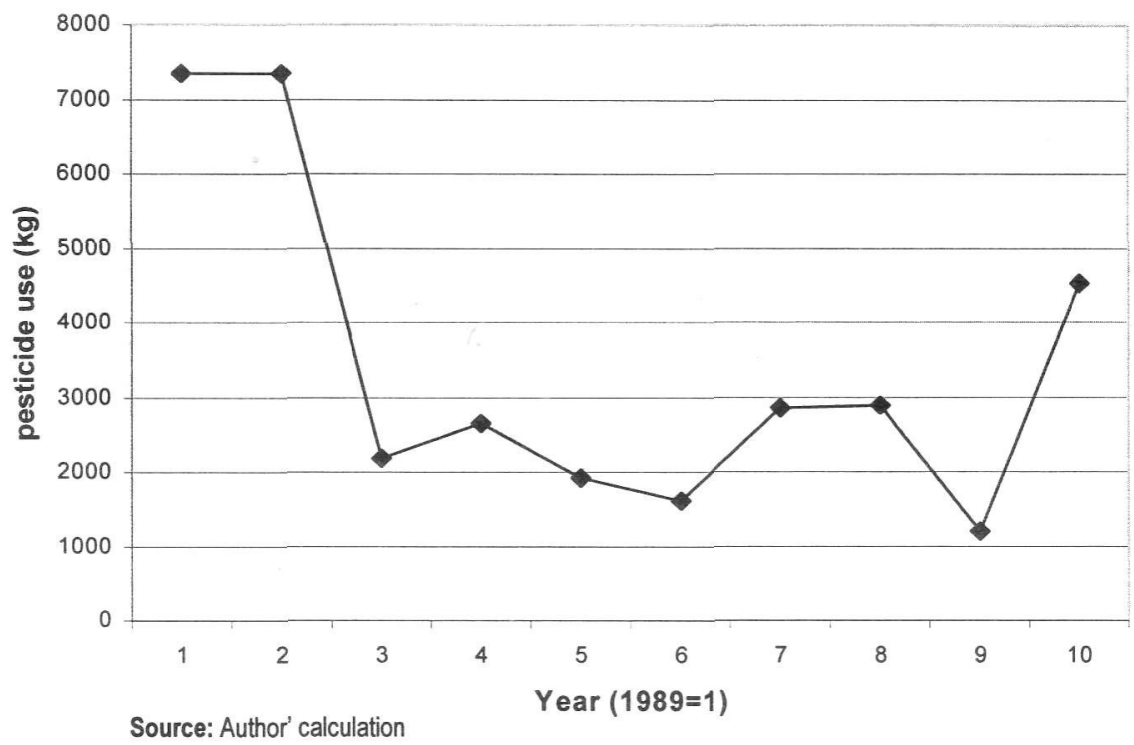

B. Rice-planted Area and Pesticide Use in Indonesia

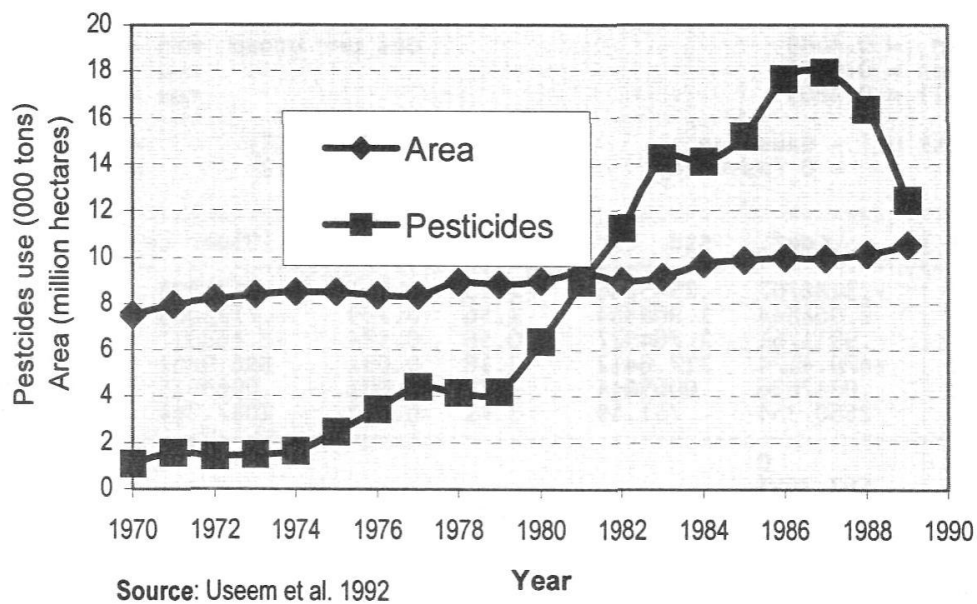




\section{Appendix 2: STATA Output}

\begin{tabular}{|c|c|c|c|c|c|c|}
\hline $\begin{array}{l}\text { Random-effects } \\
\text { Group variable }\end{array}$ & $\begin{array}{l}\text { S GLS regress } \\
\text { e (i): } 10 \mathrm{C}\end{array}$ & & & $\begin{array}{l}\text { Number of obs } \\
\text { Number of groups }\end{array}$ & $\begin{array}{l}= \\
=\end{array}$ & $\begin{array}{r}40 \\
4\end{array}$ \\
\hline $\begin{array}{ll}\text { R-sq: } & \text { within } \\
& \text { between } \\
\text { overal1 }\end{array}$ & $\begin{aligned} & =0.4702 \\
n & =0.9938 \\
1 & =0.9871\end{aligned}$ & & & Obs per group: $\begin{array}{r}\min \\
\text { avg } \\
\max \end{array}$ & $\begin{array}{l}= \\
= \\
=\end{array}$ & $\begin{array}{r}10 \\
10.0 \\
10\end{array}$ \\
\hline $\begin{array}{l}\text { Random effects } \\
\operatorname{corr}\left(u_{-} i, X\right)\end{array}$ & $\begin{aligned} \text { s } u_{-} i & \sim \text { Gauss } \\
& =0 \text { (as }\end{aligned}$ & $\begin{array}{l}\text { an } \\
\text { umed) }\end{array}$ & & $\begin{array}{l}\text { wald chi2(5) } \\
\text { Prob > chi2 }\end{array}$ & $\begin{array}{l}= \\
=\end{array}$ & $\begin{array}{r}2611.13 \\
0.0000\end{array}$ \\
\hline qpadi & coef. & Std. Err. & $z$ & [95per ce & ent & Conf. Interval] \\
\hline $\begin{array}{r}\text { hpad } \\
\text { hpest } \\
\text { hf } \\
\text { lnt } \\
\text { 7pad } \\
\text { _cons }\end{array}$ & $\begin{array}{r}31.73608 \\
-7.689514 \\
-18.16724 \\
9517.1 \\
5.810374 \\
10961.33\end{array}$ & $\begin{array}{r}39.17572 \\
5.223607 \\
36.2213 \\
4466.614 \\
.1347211 \\
15424.76\end{array}$ & $\begin{array}{r}0.81 \\
-1.47 \\
-0.50 \\
2.13 \\
43.13 \\
0.71\end{array}$ & $\begin{array}{r}-45.04692 \\
-17.9276 \\
-89.15969 \\
762.6966 \\
5.546325 \\
-19270.64\end{array}$ & & $\begin{array}{l}108.5191 \\
2.548568 \\
52.82521 \\
18271.5 \\
6.074422 \\
41193.31\end{array}$ \\
\hline $\begin{array}{r}\text { sigma_u } \\
\text { sigma_e } \\
\text { rho }\end{array}$ & $\begin{array}{r}0 \\
7461.4746 \\
0\end{array}$ & (fraction & & (e due to $u_{-} i$ ) & & \\
\hline
\end{tabular}

- test hpad hpest hf

(1) hpad $=0$

(3) hf h $^{2}=0$

$$
\begin{aligned}
\operatorname{chi} 2(3) & =12.46 \\
\operatorname{Prob}>\text { chi2 } & =0.0060
\end{aligned}
$$

\begin{tabular}{|c|c|c|c|c|}
\hline $\begin{array}{l}\text { Random-effects } \\
\text { Group variable }\end{array}$ & $\begin{array}{l}\text { GLS regression } \\
\text { (i): } 10 \mathrm{C}\end{array}$ & & $\begin{array}{l}\text { Number of obs } \\
\text { Number of groups }\end{array}$ & $\begin{array}{r}40 \\
4\end{array}$ \\
\hline $\begin{array}{ll}\text { R-sq: } & \text { within } \\
& \text { between } \\
& \text { overall }\end{array}$ & $\begin{array}{l}=0.4089 \\
=0.9778 \\
=0.4863\end{array}$ & & obs per group: $\begin{array}{r}\min \\
\text { avg } \\
\max \end{array}$ & $\begin{array}{r}10 \\
10.0 \\
10\end{array}$ \\
\hline $\begin{array}{l}\text { Random effects } \\
\operatorname{corr}\left(u_{-} i, x\right)\end{array}$ & $\begin{aligned} u_{-} i & \sim \text { Gaussian } \\
& =0 \text { (assumed) }\end{aligned}$ & & $\begin{array}{l}\text { Wald chi2(5) } \\
\text { Prob > chi2 }\end{array}$ & $\begin{array}{l}=\quad 32.18 \\
=\quad 0.0000\end{array}$ \\
\hline pest & Std. Err. & $z$ & [95per ce & ent conf. Interval] \\
\hline $\begin{array}{r}\text { hpest } \\
\text { hpad } \\
\text { hf } \\
\text { lnt } \\
\text { lpad } \\
\text { cons }\end{array}$ & $\begin{array}{r}2.3186707 \\
.9911761 \\
-470.4174 \\
.0212636 \\
2560.354\end{array}$ & $\begin{array}{r}-1.25 \\
1.56 \\
0.56 \\
-2.16 \\
3.24 \\
3.41\end{array}$ & $\begin{array}{r}-.8175336 \\
-.7725005 \\
-2.468017 \\
-896.9862 \\
.0083975 \\
1087.264\end{array}$ & $\begin{array}{r}.1801922 \\
6.710188 \\
4.450369 \\
-43.84852 \\
.0341297 \\
4033.443\end{array}$ \\
\hline $\begin{array}{l}\text { sigma_u } \\
\text { sigma_e } \\
\text { rho }\end{array}$ & $\begin{array}{r}0 \\
562.3555 \\
0\end{array}$ & & 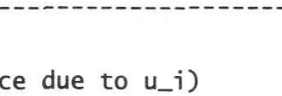 & \\
\hline
\end{tabular}

- xtreg pest hpest hpad hf 1nt 1pad

- test hpest hpad hf

$\begin{array}{ll}\text { (1) } & \text { hpest }=0 \\ \text { 2) } & \text { hpad }=0 \\ \text { (3) } & \text { hf }=0\end{array}$

$$
\begin{aligned}
& \operatorname{chi2}(3)=8.53 \\
& \text { Prob }>\text { chi2 }=0.0362
\end{aligned}
$$

- $\log$ close 